O. Tymochko ${ }^{1}$, V. Larin ${ }^{1}$, S. Osiievskyi ${ }^{1}$, O. Timochko ${ }^{2}$, A. Abdalla ${ }^{3}$

${ }^{1}$ Ivan Kozhedub Kharkiv National Air Force University, Kharkiv, Ukraine

${ }^{2}$ Kreditech Holding, Hamburg, Germany

${ }^{3}$ Flight Academy of National Aviation University, Kropyvnytskyi, Ukraine

\title{
METHOD OF PROCESSING VIDEO INFORMATION RESOURCE FOR AIRCRAFT NAVIGATION SYSTEMS AND MOTION CONTROL
}

\begin{abstract}
It has been considered the existing methods of processing of video information resource in modern aircraft navigation systems and motion control. Also it is indicated that there is a contradiction between the need to reduce the intensity of information resource for strongly saturated fragments and to maintain the correspondence of recovered fragments to the original aerial photo. It has been described the components' characteristics of the transforming for the image's areas with varying structure complexity. The rationalization of the dividing strategy is based on the complexity of aerial photographs is substantiated. It is proposed to quantize the transformation's description of an aerial video information segment in relation to the base element's value vector to a certain threshold value. The reduction of combinatorial redundancy as a result of the application of top-level quantized levels array in a separable space is substantiated.
\end{abstract}

Keywords : image; aerial photo; transforms; redundancy; coding; quantization; orthogonal transformation; matrix; data; high-frequency component.

\section{Introduction}

Problem statement. The rapid development of information technologies led to the use of unidirectional specific images transmission in surveillance systems. According to that, in order to improve the quality of management systems in public institutions, active implementation of such systems is taking place [1]. As a result, in the departmental organizations, especially in the Ukrainian space program, aeronautical monitoring systems with the using airless aircrafts are widely distributed. As a result of the observation, the specific image receiving with the help of aerial photography. Due to the importance of the resulting image's content, it is necessary to minimize the time for the processing and bringing the given aerial photo in conditions of maintaining the necessary level of the restored image's correspondence to the original [2]. In the process of aerial photography, in various specialized devices, the mathematical description of the image is used as a twodimensional signal, which is characterized by some volume of information [3].

Research publications. In order to justify the problem solution, it is necessary to consider the existing technologies for the processing of aerial photographs. These technologies (JPEG, JPEG 2000) use processing, which is based on static coding (variable length codes) [4]. In the processing of aerial photographs in various specialized devices, a mathematical description of the image is used as a two-dimensional signal, which is characterized by some volume of information [5]. When encoding the image, the elimination of psycho-visual redundancy with applying the previous transformation and further rationing. The corresponding scheme of basic technology is shown in Fig. 1

The research aims and objectives. When performing basic technology, the initial information intensity's value of the output data stream is formed after the normalization step [6]. The effectiveness of the base technology is expressed in the information intensity reduction, which physically leads to a time reduction for the delivery of aerial photographs. At the same time, there is a problem with the restored image's quality at high ratios [7].

Therefore, the purpose of the research is to create a separation strategy of valuation, taking into account the structural saturation and substantiation of the approach to the formation of the transformation's quantized description of the aerial photo's segment.

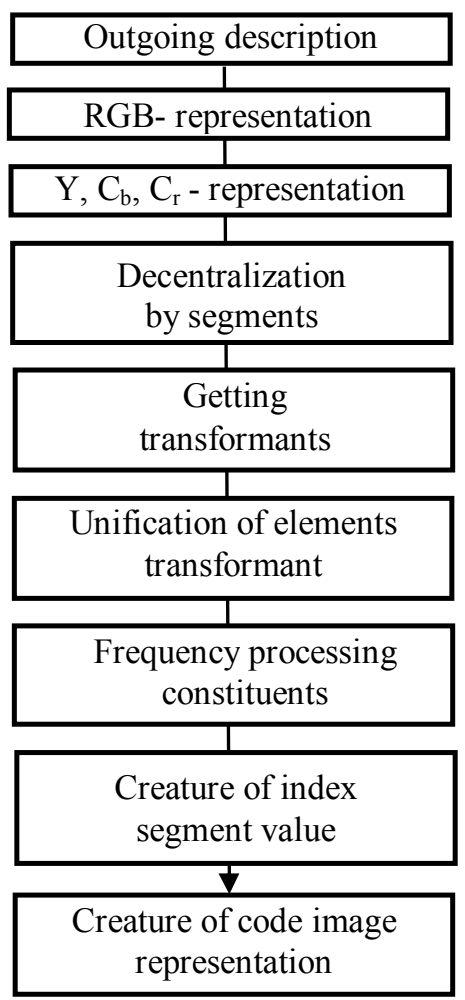

Fig. 1. The scheme of the basic technology is effective coding using previous transformation and subsequent normalization

\section{Research bases}

To create this strategy, it is necessary to consider the process of valuation in more detail. When digital 
processing of the analog signal is a change in the representation of a wide (and continuous) range of input values in a limited set of discrete output values. The term "normalization", in the case of image processing, involves the rounding of real numbers to integers or the transformation of integers into smaller targets [8].

The feature of human sight is the fact that as a result of the low sensitivity to the change of highfrequency components of the image it is possible to apply a coarse quantization step to the coefficients responsible for the high frequencies [9]. The normalization occurs as a result of the division of the matrix of coefficients $\mathrm{k}$ into the so-called estimated matrix Ei.e.

$$
K_{i j}=\left\lfloor k_{i j} / e_{i j}\right\rfloor
$$

where $k_{i j}$ - values of the transformant components;

$e_{i j}$-values of the normalization matrix components;

$\lfloor k\rfloor$-operation of determining the whole part $k$.

Usually, the normalization matrix is different for the components of color and brightness [10]. In most algorithms of image processing, the normalization is in the usual elemental division of a certain working matrix's values of the components into a valuation matrix [11]. For each component of the color difference model (Y, U and V), its own estimation matrix is given $e=[\chi, \delta]$. Application is given by the following formula:

$$
K_{i j}{ }^{(G)}=\left\lfloor\frac{k_{i j}}{e_{i j}}\right\rfloor .
$$

At this stage, by varying the compression ratio, the amplitudes of the transformant components' output values are set, and, consequently, the level of losses is determined [12]. With the use of a valuation matrix with coefficients' large values, a greater number of zeros is obtained and, consequently, a greater compression degree.

From this it follows that when forming the normalization matrixes, at the stage of the setting the values of their elements, there is the possibility to control the compression degree [13]. As a result, at a higher value of the elements of the valuation matrix, the range of values of elements of the normalized transformant

$$
K^{(G)}=[\chi, \delta],
$$

will be less. It leads to the possibility of encoding with less information. For example, in the JPEG standard, normalization matrixes are obtained empirically [14]. Recommendations in the standard JPEG, the normalization data for the component of brightness are presented in the table 1 .

Table 1 - Rendering data for component of brightness

\begin{tabular}{|c|c|c|c|c|c|c|c|c|}
\hline$j$ & 1 & 2 & 3 & 4 & 5 & 6 & 7 & 8 \\
\hline 1 & 11 & 16 & 16 & 10 & 40 & 24 & 61 & 51 \\
\hline 2 & 12 & 12 & 19 & 14 & 58 & 26 & 55 & 60 \\
\hline 3 & 13 & 14 & 24 & 16 & 57 & 40 & 56 & 69 \\
\hline 4 & 17 & 14 & 29 & 22 & 87 & 51 & 62 & 80 \\
\hline 5 & 22 & 18 & 56 & 37 & 109 & 58 & 77 & 103 \\
\hline 6 & 35 & 24 & 64 & 55 & 104 & 81 & 92 & 113 \\
\hline 7 & 64 & 49 & 87 & 78 & 121 & 103 & 101 & 120 \\
\hline 8 & 92 & 72 & 98 & 95 & 100 & 112 & 99 & 103 \\
\hline
\end{tabular}

The elements' values of these matrixes for the standard JPEG are obtained in an experienced way as a result of the visual perception estimating [15].

To change the value of the compression ratio, the multiplication of the initial matrixes is made on a certain number [16].

The JPEG 2000 standard implies the use of its own table of valuation, but it is required to transmit the decoder together with the compressed data. It leads to an increase in the total size of the encoded data [17]. As an alternative, it is possible to create own normalization matrixes (stream processing) using one parameter $P$, which is defined by the user.

As a result of applying the normalization for the algorithm, some specific effects will be characteristic for large values of the compression ratio [18]. Losses in the field of low-frequency components lead to the appearance of the resulting image of the squares. Loss of high-frequency components cause the so-called
"Gibbs effect", when around the elements of aerial photography with a sharp drop in structural saturation appears some halo [19].

The JPEG and JPEG 2000 algorithms are used to compress the image, followed by its visual perception, and the resulting compressed image is not suitable for further digital processing [20].

As a result, it is possible to make a conclusion: valuation is used for: saving memory; change in the characteristics of the sequences with respect to further compression; adjusting the compression ratio and, accordingly, the level of losses; preparation for further processing; add effects [21].

\section{Formation of a quantized description of the aerial photograph's transformation}

As a result of detecting the dependencies of dynamic ranges' unevenness and their limitations for aerial photographs with different parameters of 
structural complexity. It is given the opportunity to reduce the amount of statistical redundancy by applying structural-block coding in the method of processing aerial photographs [22].

In order to do this, the processing parameters are determined in the course of normalization on the basis of structural complexity's parameters. This leads to the formation of a spectral single-normalized space [23].

The components transformants' value $K^{(e)}$ is characterized by a dynamic range of components $k_{m \ell}$ in a two-dimensional space, taking into account the ranges of rows $\Delta_{m}$ and columns $\Delta_{\ell}$ as magnitudes $\Delta_{m \ell} \Delta_{m \ell}=\min \left(k_{\ell, \max }+1 ; k_{m, \max }+1\right)$.

Here $\Delta_{m \ell}-$ is the range of the component $k_{m \ell}$; $\Delta_{\ell, \max }$ - the value of the range $\ell$ - th column transformants $k ; \Delta_{m \text {, max }}$ - the value of the range of the k- th line transformants $k$.

In order to reduce the volume of compressed aerial photographs, it is proposed to use quantization, which is formed when the components of the transformants with a high dynamic range of values are detected (Fig. 2).

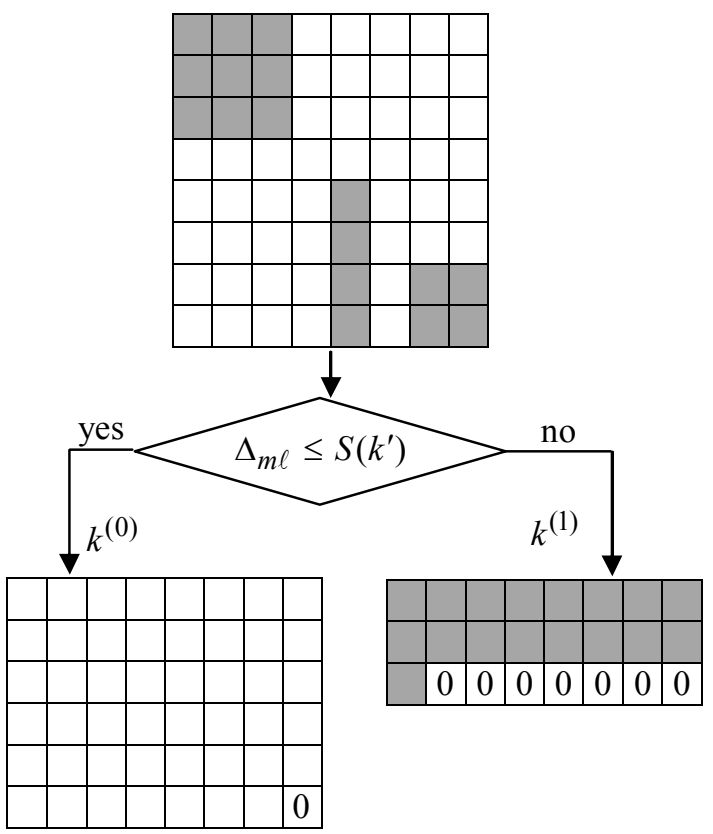

Fig. 2. Structural and functional quantization scheme of the array of separate representation

At quantization, the initial array distribution of a separate representation $K^{\prime}=\left\{k_{m \ell}^{\prime}\right\}$ is divided into two components $k^{(0)}$ and $k^{(1)}$.

Affiliation to these components is determined by the value's ratio $\Delta_{m \ell}$ of one level of the array's dynamic range of differential representation, that is

$$
k \stackrel{S\left(k^{\prime}\right)}{\longrightarrow}\left\{k^{(0)} ; k^{(1)}\right\},
$$

where $k^{(0)}, k^{(1)}$ - the constituents of the array of a separate representation, which include, respectively, the elements of the lower and upper quantized levels [24].
Quantization in massifs of differential representation arises as a result of the combined approach in the process of its formation [25-28]. As a result, a dynamic range of an array of differential representation is formed. Which structure has at least two gradations. From this, it follows that quantization is the elimination of structural redundancy.

In this case, the elimination of the disadvantage, the cause of which is the high dynamic range of individual elements of the array of differential representation, is possible. This is achieved by the following characteristics of the component $k^{(1)}$ of the upper quantized level:

- in the array of the upper range level of the quantized representation, there are elements corresponding to the differences at the boundary of the contour and the main background of the fragment aerial photography;

- for the elements that corresponds to the boundary of the contour and the main background of the fragment aerial photography, is characterized by a uniform dynamic range.

These characteristics are used in the separate description of the component of the upper quantized level. In a separate arrays representation of the upperlevel, elements of the array are represented as twodimensional position numbers in difference space. In this case, the array code $k^{(1)}$ will be determined in relation to the code number that corresponds to the minimum level $V^{(2)}$ of the separate space.

In connection with this, it is proposed to take into account the minimum values in each array's row of the upper quantized level in the process of forming the minimum level of separation space. In this case, a vector of minimal values in the lines is formed,

$$
V=\left\{v_{1}, \ldots, v_{\beta}\right\} \text {. }
$$

The value $v_{i}$ is calculated as the minimum value in the $i$ - $\mathrm{u}$ row of the array $k^{(1)}$ i.e.

$$
v_{i}=\min _{1 \leq j \leq \delta}\left\{k_{i j}^{(1)}\right\}, \quad i=\overline{1, \alpha} .
$$

Determining the minimum values for each line allows taking into account the features of dynamic ranges at the boundaries of aerial photography [29].

As a result, the displacement from the initial dynamic range of the array $k^{(1)}$ to the reduced dynamic range, which is given by the vector of restrictions Vent, i.e. Vent $=\left\{\right.$ vent $_{1 j}, \ldots$, vent $\left._{\delta}\right\}$.

Here $v^{2} t_{i j}$ - is the difference between the maximum $\Delta_{i j}^{(1)}$ and minimum $v_{i}$ values in the $\mathrm{i}-$ th line of the array $k^{(1)}$ of the upper quantized level, that is

$$
\text { vent }_{i j}=\Delta_{i j}^{(1)}-v_{i} \text {. }
$$

The lower level $V^{(2)}$ of the two-dimensional separation space is calculated, which is based on the 
values of the vector's elements $V=\left\{v_{1}, \ldots, v_{z}\right\}$. The lower-level elements $V^{(2)}$ are set by restrictions on the dynamic range of the upper quantized level.

Therefore, the distance Dist between the current array $k^{(1)}$ and the lower level $V^{(2)}$ of the twodimensional number is calculated according to the following formula:

$$
\begin{gathered}
\text { Vent }= \\
=\sum_{i=1}^{\chi} \sum_{j=1}^{\delta^{(1)}}\left(k_{i j}^{(1)}-v_{i}\right) \prod_{\xi=j+1}^{\delta^{(1)}} \text { vent }_{i \xi} \alpha \prod_{\gamma=i+1}^{\delta} \prod_{\xi=1}^{\chi^{(1)}} \text { vent }_{\gamma \xi} .
\end{gathered}
$$

Here $\left(k_{i j}^{(1)}-v_{i}\right)=\bar{k}_{i j}^{(1)}$ - is - the displacement's value of the current array's elements in the lower level of a two-dimensional space, whose position index is equal $(i ; j)$.

Let's substantiate the necessity of representing an array $k^{(1)}$ in a two-dimensional separation space. To do this $f^{(1)}$ we will write the value of the code in the initial space:

$$
f^{(1)}=\sum_{i=1}^{\chi} \sum_{j=1}^{\delta^{(1)}} k_{i j}^{(1)} \prod_{\xi=j+1}^{\delta^{(1)}} \Delta_{i \xi}^{(1)} \prod_{\gamma=i+1}^{\chi} \prod_{\xi=1}^{\delta^{(1)}} \Delta_{\gamma \xi}^{(1)} .
$$

Let's write the relationship and get it

$$
\begin{gathered}
\text { Vent }=\sum_{i=1}^{\chi} \sum_{j=1}^{\delta^{(1)}}\left(k_{i j}^{(1)}-v_{i}\right) \prod_{\xi=j+1}^{\delta^{(1)}}\left(\Delta_{i \xi}^{(1)}-\right. \\
\left.-v_{i}\right) \prod_{\xi=j+1}^{\delta^{(1)}}\left(\Delta_{i \xi}^{(1)}-v_{i}\right) \prod_{\gamma=i+1}^{\chi} \prod_{\xi=1}^{\delta^{(1)}}\left(\Delta_{\gamma \xi}^{(1)}-v_{\gamma}\right) .
\end{gathered}
$$

Then, since the inequalities are fulfilled:

$$
\begin{gathered}
\left(k_{i j}^{(1)}-v_{i}\right) \leq k_{i j}^{(1)} ; \\
\prod_{\xi=j+1}^{\delta^{(1)}}\left(\Delta_{i \xi}^{(1)}-\mu_{i}\right) \prod_{\gamma=i+1}^{\chi} \prod_{\xi=1}^{\chi}\left(\Delta_{\gamma \xi}^{(1)}-\right. \\
\left.-\mu_{\gamma}\right) \leq \prod_{\xi=j+1}^{\delta^{(1)}} \Delta_{i \xi}^{(1)} \prod_{\gamma=i+1}^{\chi} \prod_{\xi=1}^{\delta^{(1)}} \Delta_{\gamma \xi}^{(1)},
\end{gathered}
$$

then it has led to the expression:

$$
\text { Vent } \leq f^{(1)} \text {. }
$$

In this case, the code number Dist in a separate space, determined as a relative distance, will be less than the difference between the code number and the code of the lower level $f_{\min }^{(1)}$ in the original quantized space, that

$$
V e n t \leq f^{(1)}-f_{\min }^{(1)} .
$$

The truth of expression (1) is proved by the fact that the use of the representation of array's elements of the upper quantized level in a separable space leads to the elimination of combinatorial redundancy, which is achieved:

- a decrease in the values distribution of the upper quantized level's elements due to the detection of minimum values, that is, the implementation of inequalities

$$
\left(k_{i j}^{(1)}-v_{i}\right) \leq k_{i j}^{(1)}
$$

and

$$
\left(\Delta_{i j}^{(1)}-v_{i}\right) \leq \Delta_{i j}^{(1)} ;
$$

- the number reduction of numbers for which the condition of the differential space is not followed and preceded by the current number [30].

The total number $N u m b^{(2)}$ of position numbers for which the condition in the differential nonequilibrium space is fulfilled is calculated according to the following expression

$$
N u m b^{(2)}=\prod_{1}^{\chi} \prod_{j=1}^{\delta^{(1)}}\left(\Delta_{i j}^{(1)}-v_{i}\right) .
$$

Formula (2) indicates a reduced combinatorial redundancy as a result of applying the representation of the array of the upper quantized level in a separable space [31]. This leads to a reduction in the time expended on bringing highly saturated image fragments.

\section{Conclusions}

1. It has been developed the strategy for managing time expenditures for the realization of aerial photos by applying adaptive normalization of the components of the image segment.

2. It has been developed an approach to the formation of a quantized description of the aerial image segment's transformation, which is based on the twolevel representation of the transformant's dynamic range of values, which reduces combinatorial redundancy.

\section{REFERENCES}

1. Piramanayagam, S., Saber, E., Cahill, N.D. and Messinger, D. (2015), "Shot boundary detection and label propagation for spatio-temporal video segmentation", Proceedings of SPIE - The International Society for Optical Engineering, 9405.

2. Mashtalir, S., Mikhnova, O. and Stolbovyi, M. (2018), "Sequence Matching for Content-Based Video Retrieval", Proceedings of the 2018 IEEE 2nd International Conference on Data Stream Mining and Processing, DSMP 2018, art. no. 8478597 , pp. 549-553.

3. Ruban, I., Smelyakov, K., Vitalii, M., Dmitry, P. and Bolohova, N. (2018), "Method of neural network recognition of ground-based air objects", Proceedings of 2018 IEEE 9th International Conference on Dependable Systems, Services and Technologies, DESSERT 2018, pp. 589-592.

4. Sumtsov, D., Osiievskyi, S. and Lebediev, V. (2018), "Development of a method for the experimental estimation of multimedia data flow rate in a computer network", Eastern-European Journal of Enterprise Technologies, Vol. 2, Is. 2-92, pp. 56-64. 
5. Sindeev, M., Konushin, A. and Rother, C. (2012), "Alpha-flow for video matting", Technical Report, pp. 41-46.

6. Hubbard, T. and Bor, R. (2016), Aviation Mental Health: Psychological Implications for Air Transportation, Routledge, London, $376 \mathrm{p}$.

7. Buranova, M.A., Kartashevskyi, V.H. and Samoilov, M.S. (2013), "The comparative analysis of statistical characteristics of the video traffic in networks of the packet transmission of data", Infokommunikacionnye tehnologii, Vol. 11, Is. 4, pp. 33-39.

8. Mistry, D., Modi, P., Deokule, K., Patel, A., Patki, H. and Abuzaghleh, O. (2016), "Network traffic measurement and analysis", 2016 IEEE Long Island Systems, Applications and Technology Conference (LISAT), April 2016, DOI: https://doi.org/10.1109/LISAT.2016.7494141

9. Tkachov V.M., Tokariev V.V., Radchenko V.O. and Lebediev V.O. (2017), "The Problem of Big Data Transmission in the Mobile "Multi-Copter - Sensor Network" System", Control, Navigation and Communication Systems, Issue 2, pp. 154-157.

10. Svyrydov, A., Kuchuk, H., Tsiapa, O. (2018), "Improving efficienty of image recognition process: Approach and case study", Proceedings of 2018 IEEE 9th International Conference on Dependable Systems, Services and Technologies, DESSERT 2018, pp. 593-597, DOI: http://dx.doi.org/10.1109/DESSERT.2018.8409201

11. Krasnorutskij, A., Tristan, A. and Kharchenko, N. (2014), "The Problem Aspect of Control of Bit Speed of the Video Stream in Telecommunication Networks", International Conference TCSET'2014 ["Modern problems of radio engineering, telecommunications, and computer science"] (Lviv-Slavske, Ukraine, February 25 - March 1, 2014) / Lviv Polytechnic National University, 2014. - P. 533-534.

12. Mozhaev, O., Kuchuk H., Kuchuk, N., Mozhaev, M. and Lohvynenko M. (2017), "Multiservise network security metric", IEEE Advanced information and communication technologies-2017, Proc. of the 2th Int. Conf, Lviv, pp. 133-136, DOI: https://doi.org/10.1109/AIACT.2017.8020083

13. Wang, S., Zhang, X., Liu, X., Zhang, J., Ma, S. and Gao, W. (2017), "Utility-Driven Adaptive Preprocessing for Screen Content Video Compression", IEEE Transactions on Multimedia, 19 (3), art. no. 7736114, pp. 660-667.

14. Pavlenko, M., Timochko, A., Korolyuk, N. and Gusak M. (2014), "Hybrid model of knowledge for situation recognition in airspace", Automatic Control and Computer Sciences, Vol. 48, Issue 5, pp. 257-263.

15. Taylor, S.E. (2015), Health psychology, McGraw-Hill Education, New York, 2015, 430 p.

16. Popovskiy, V.V., Saburova, S.O., Oliynik, V.F., Losev, Yu.I. and Ageev D.V. (2006), Matematichni osnovi teoriyi telekomunIkatsiynih system, TOV «Kompaniya SMIT», Kharkiv, 564 p. (in Russian)

17. Pavlenko, M.A. (2012), "Methods and procedures for the selection of operators using smart automated decision support systems", Zbirnik naukovih prac HUPS, No. 4 (33), pp. 171-177.

18. Kharchenko, V. and Mukhina, M. (2014), "Correlation-extreme visual navigation of unmanned aircraft systems based on speed-up robust features", Aviation, Vol. 18, Issue 2, pp. 80-85, DOI: https://doi.org/10.3846/16487788.2014.926645.

19. Brown, T.A. (2015), Confirmatory factor analysis for applied research, Guilford Press, New York, $462 \mathrm{p}$.

20. Gonzales, R.C. and Woods, R.E. (2002), Digital image processing, Prentice Inc. Upper Saddle River, New Jersey, 779 p.

21. Ericsson, K.A., Charness, N., Feltovich, P.J. and Hoffman, R.R. (2018), The Cambridge handbook of expertise and expert performance, Cambridge University Press, New York, 918 p.

22. Wickens, C.D. (2015), Engineering psychology and human performance, Psychology Press, New York, 544 p.

23. Li, L. (2015), "The UAV intelligent inspection of transmission lines", Proceedings of the 2015 International Conference on Advances in Mechanical Engineering and Industrial Informatics, DOI: https://doi.org/10.2991/ameii-15.2015.285.

24. Carter, M.W. and Price, C.C. (2017), Operations research: a practical introduction, CRC Press, Boca Raton, 416 p.

25. Fletcher, R. (2017), Practical methods of optimization, John Wiley \& Sons, New York, 456 p.

26. Ruban, I., Kuchuk, H. and Kovalenko A. (2017), "Redistribution of base stations load in mobile communication networks", Innovative technologies and scientific solutions for industries, No 1 (1), P. 75-81, doi : https://doi.org/10.30837/25229818.2017.1.075

27. Kuchuk, G., Kovalenko, A., Komari, I.E., Svyrydov, A. and Kharchenko, V. (2019), "Improving big data centers energy efficiency: Traffic based model and method", Studies in Systems, Decision and Control", vol 171, Kharchenko, V., Kondratenko, Y., Kacprzyk, J. (Eds.), Springer Nature Switzerland AG, pp. 161-183, DOI: http://doi.org/10.1007/978-3-03000253-4 8

28. Kuchuk, G., Nechausov, S. and Kharchenko, V. (2015), "Two-stage optimization of resource allocation for hybrid cloud data store”, Int. Conf. on Information and Digital Techn., Zilina, pp. 266-271, DOI: http://dx.doi.org/10.1109/DT.2015.7222982

29. Larin, V., Yeromina, N., Petrov, S., Tantsiura, A. and Iasechko, M. (2018), "Formation of reference images and decision function in radiometric correlation-extremal navigation systems", Eastern-European Journal of Enterprise Technologies, Vol. 4, Is. 9, pp. 27-35.

30. Qassim, H., Verma, A. and Feinzimer, D. (2018), "Compressed residual-VGG16 CNN model for big data places image recognition”, 2018 IEEE 8th Annual Computing and Communication Workshop and Conference (CCWC), DOI: https://doi.org/10.1109/ccwc.2018.8301729.

31. Larin, V., Yerema, D. and Bolotska Y. (2019), "The reasoning of necessity enhancing video privacy in conditions of providing the quality of the video information service provided in virtual infocommunication systems", Sistemi ozbroennya $i$ viyskova tehnika, Vol. 2 (35), HNUPS, Kharkiv, pp. 158-162.

Надійшла (received) 25.11.2019

Прийнята до друку (accepted for publication) 05.02.2020

Відомості ПРо АвтоРів / AвоUT тHE AUTHORS

Тимочко Олександр Іванович - доктор технічних наук, професор, професор кафедри, Харківський національний університет Повітряних Сил імені Івана Кожедуба, Харків, Україна;

Oleksandr Tymochko - doctor of Technical Sciences, Professor, Department Professor, Ivan Kozhedub Kharkiv National Air Force University, Kharkiv, Ukraine;

e-mail: timochko.alex@gmail.com; ORCID ID: http://orcid.org/0000-0002-4154-7876. 
Ларін Володимир Валерійович - кандидат технічних наук, доцент кафедри математичного та програмного забезпечення ACУ, Харківський національний університет Повітряних Сил імені Івана Кожедуба, Харків, Україна; Volodymyr Larin - Candidate of Technical Sciences, Associate Professor of Mathematical and Software ACS Department, Ivan Kozhedub Kharkiv National Air Force University, Kharkiv, Ukraine;

e-mail: Volodymyr Larin@gmail.com; ORCID ID: http://orcid.org/0000-0003-0771-2660.

Осісвський Сергій Валерійович - кандидат технічних наук, доцент, доцент кафедри математичного та програмного забезпечення АСУ, Харківський національний університет Повітряних Сил імені Івана Кожедуба, Харків, Україна; Serhii Osiievskyi - Candidate of Technical Sciences, Associate Professor, Associate Professor of Mathematical and Software ACS Department, Ivan Kozhedub Kharkiv National Air Force University, Kharkiv, Ukraine; e-mail: Serhii_Osiievskyi@gmail.com; ORCID ID: http://orcid.org/0000-0003-0861-9417.

Тімочко Олександр Олександрович - кандидат технічних наук, інженер фірми «Kreditech», Гамбург, Німеччина; Oleksandr Timochko - Expert Quality Assurance Engeneer of Kreditech Holding, Hamburg, Germany; e-mail: timochko.alexandr.a@gmail.com; ORCID ID: http://orcid.org/0000-0003-0424-0426.

Ахмед Абдалла - аспірант, Льотна академія Національного авіаційного університету, Кропивницький, Україна; Ahmed Abdalla - doctoral Student, Flight Academy of National Aviation University, Kropyvnytskyi, Ukraine; e-mail: Ahmed_Abdalla@gmail.com; ORCID ID: http://orcid.org/0000-0001-9830-9548.

\section{Метод обробки відеоінформаційних ресурсів для систем навігації та управління рухом}

\section{О. І. Тимочко, В. В. Ларін, С. В. Осієвський, О. О. Тімочко, Ахмед Абдалла}

Анотація. У статті розглядаються існуючі технології обробки видових зображень в сучасних засобах навігації та управління рухом. Вказується на наявність протиріччя між необхідністю зменшувати інформаційну інтенсивність для сильнонасичених фрагментів та підтримки відповідності відновлених фрагментів вихідному аерофотознімку об'єктів інтересу. Описуються характеристики компонент матриці після ортогонального перетворення для ділянок зображення 3 різною структурною насиченістю. Обгрунтовується застосування роздільного правила нормування 3 урахуванням структурної складності аерофотознімків об'єктів інтересу. Пропонується проводити обробку значень елементів трансформанти сегменту аерофотознімка об'єктів інтересу по відношенню значення елементу вектору основи до деякого заданого порогового значення. Обгрунтовується скорочення комбінаторної надмірності в результаті застосування подання масиву верхнього квантованого рівня в роздільному просторі. Розроблено політику керування часовими витратами на доведення даних аерофотознімка шляхом застосування адаптивної нормалізації компонент елементів відеоінформаційного ресурсу. Розроблений критерій до формування частотного опису матриці після ортогонального перетворення сегменту аерофотознімка на основі дворівневого представлення динамічного діапазону значень трансформанти, що дозволяє скоротити комбінаторну надмірність.

Кл юч ов і сл ов а : зображення; аерофотозйомка; надмірність; кодування; квантування; ортогональне перетворення; матриця; дані; високочастотний компонент.

\section{Метод обработки видеоинформационных ресурсов для систем навигации и управления движением}

\section{А. И. Тимочко, В. В. Ларин, С. В. Осиевский, А. А. Тимочко, Ахмед Абдалла}

Аннотация. В статье рассматриваются существующие технологии обработки видовых изображений в современных средствах навигации и управления движением. Указывается на наличие противоречия между необходимостью уменьшать информационную интенсивность для сильнонасыщенных фрагментов и поддержания соответствия восстановленных фрагментов исходному аэрофотоснимку объектов интереса. Описываются характеристики компонент матрицы после ортогонального преобразования для участков изображения с разной структурной насыщенностью. Обосновывается применение раздельного правила нормирования с учетом структурной сложности аэрофотоснимков объектов интереса. Предлагается проводить обработку значений элементов трансформанты сегмента аэрофотоснимка объектов интереса по отношению значения элемента вектора основания до некоторого заданного порогового значения. Обосновывается сокращение комбинаторной избыточности в результате применения представления массива верхнего квантованного уровня в раздельном пространстве. Разработана политика управления временными затратами на доведение данных аэрофотоснимка путем применения адаптивной нормализации компонент элементов видеоинформационного ресурса. Разработанный критерий к формированию частотного описания матрицы после ортогонального преобразования сегмента аэрофотоснимка на основе двухуровневого представления динамического диапазона значений трансформанты, что позволяет сократить комбинаторную избыточность.

Ключевые слова: изображение; аэрофотосъемка; избыточность; кодирование; квантование; ортогональное преобразование; матрица; данные; высокочастотный компонент. 